IRA-International Journal of Management \&

Social Sciences

ISSN 2455-2267; Vol.17, Issue 04 (Q.4 2021)

Pg. no. 121-129.

IRA Academico Research

\title{
Public Capita and Growth: The Role of Institutions in Development
}

\section{Fred EKA (iD}

Department of Economic Analysis and Policy. Research Group in Economics and Management (GREG), University of Douala, BP 4032, Cameroon.

Type of Work: Peer Reviewed.

DOl: https://dx.doi.org/10.21013/jmss.v17.n4.p3

\section{How to cite this paper:}

EKA, F. (2021). Public Capita and Growth: The Role of Institutions in Development. IRA-International Journal of Management \& Social Sciences (ISSN 2455-2267), 17(4), 121-129.

DOI: https://dx.doi.org/10.21013/jmss.v17.n4.p3

(c) IRA Academico Research.

This full-text of this paper is available under Open Access subject to a Creative Commons Attribution-NonCommercial 4.0 International License $\bar{C}$ and further subject to a proper citation of its primary publication source.

Disclaimer: The scholarly papers as reviewed and published by IRA Academico Research are the views and opinions of their respective authors and are not the views or opinions of IRA Academico Research. IRA Academico Research disclaims any harm or loss caused due to the published content to any party.

IRA Academico Research is an institutional publisher member of Publishers International Linking Association Inc. (PILA-CrossRef), USA. Being an institutional signatory to the Budapest Open Access Initiative, Hungary, the content published by IRA Academico Research is available under Open Access. IRA Academico Research is also a registered content provider under Open Access Initiative Protocol for Metadata Harvesting (OAI-PMH).

This paper is peer-reviewed following IRA Academico Research's Peer Review Program $\square$.

Fred EKA (id)/0000-0001-7208-2891 [ד] 


\section{ABSTRACT}

This study analyzes the links between public capital and growth using an econometric model of simultaneous equations, estimated on a panel of forty-three developing countries over the period 2003-2020. This growth model explains the determinants of GDP and public and private capital stocks. The accumulation of public, private and human capital generates externalities that are sources of endogenous growth. However, the formation of public capital generated a crowding out effect, to the detriment of that of private capital, because of differentiated budgetary constraints. Our results show that several developing countries have moved away from an optimal structure for the growth of sharing of available capital between the public and private sectors. In doing so, are institutions a prerequisite for the economic development of African countries.

JEL Codes: C33, H50, O11

Keywords: Public capital, private capital, growth, crowding out effect.

\section{Introduction}

The importance of public capital in economic growth is experiencing renewed interest because of its implications in terms of economic policy. It has often been said that the mechanisms for allocating factors in terms of investments are ineffective in the public sector. An excessive importance of the latter in economic activity could then slow down growth by reducing allocative efficiency (Dessus and Herrera, 1999).

The painful structural adjustment policies of the 1990s were aimed precisely at rebalancing investments between the public and private sectors. However, public capital, above all in infrastructure, can also be considered as a necessary complement to private investment, and as such a decisive factor for the long-term growth of the economy. The question that then arises is that of the optimal structure for sharing capital between the public and private sectors. The development of endogenous growth theories has contributed to the return of this old debate (Arrow and Kurz, 1970). In doing so, the model of (Barro, 1990), thanks to productive public expenditure assimilated to public infrastructure capital, plays a driving role in the process of self-sustaining growth over a long period. Retaining an hypothesis of complementarity between private and public capital thus amounts to attributing to the latter a positive impact of improving the productivity of capital in the private sector (Berthélemy, Herrera and Sen, 1995). But, if the theoretical links between public capital and growth ultimately pose few problems, empirical verification of the effects of public expenditure on physical capital on the product faces serious methodological difficulties at the macroeconomic level.

This article attempts to meet all of these limitations. It differs from previous work for several reasons. The first originality of this study is to measure the effects of public capital on growth for a sample of forty-three developing countries using a panel data methodology. The latter makes it possible to identify long-term relationships through the presence within the sample of countries with very unequal levels of development without having to worry about the problems linked to the order of integration of the series. A second originality is justified by the definition of the public capital that we build. This has the advantage of guaranteeing strict homogeneity of country data within the sample. The third originality of this article consists in endogenizing public and private capital stocks within the framework of a simultaneous equation model in order to reduce simultaneity biases but also to study the specific modes of public and private capital formation in the developing countries considered. The latter have in fact experienced financing difficulties in recent years, notably through their high level of external debt and restricted access by the private sector to the international capital market.

This article shows that the accumulation of public capital is a positive factor of growth. The estimate of the productive contribution of public capital to GDP growth is confirmed by the overall consistency of the production function which also integrates private physical capital and human capital, and by the values of the implicit rates of return of public and private capital stocks. Moreover, it emerges that most of the countries in the sample have invested heavily in the public relative to the private sector, which has reduced their growth potential. Despite the painful structural adjustment policies of the 1990s, several countries have not been able to close the gap in terms of production capacities in the private sector compared to the public sector.

How has public capital evolved in developing countries since the late 1990s? What are its main characteristics, and how do you measure it? Which public institutions hold this capital? How was it formed from the flow of investment and the depreciation of this capital? What is the financial situation of general government today if we take into 
account the evolution of public debt in recent years? The developments in investment are generally widely commented on, but those concerning capital are not very much. However, capital is neither more nor less than the cumulative flow of past investments, taking into account the annual depreciation of this stock of assets.

This article is organized into four parts. The second part presents the methodology for constructing capital stocks and econometric estimation. The third part presents the results of the estimation of the simultaneous equation model. The fourth part is devoted to the regulatory role that institutions must play in the development of African countries created by political will, and therefore exogenous to the economy, in particular by the force of impetus, organization and structuring. The last part draws up in the form of a conclusion an assessment of the main empirical results obtained and outlines the possible lines of investigation on the subject.

\section{Data and methodology \\ II.1. Database characteristics}

The estimate includes forty-three developing countries over the period 2003-2020, for a total of 774 observations. The choice of countries and of the period is the result of the number of observations for a sample based on available data on public investment, total stock of productive capital and human capital. All these data as well as those concerning the GDP, the total external debt and the rate of openness of the economy come from the World Bank and IEC Capital Stock (Data Nehru and Dhareshwar, 1993). The latter database provides stocks of human capital and total physical capital. The first is defined as the product of the average number of years of schooling per capita by the working population. The second is calculated by the perpetual inventory method, using gross fixed capital formation (GFCF) as an investment measure. The initial capital of each country is estimated using the Harberger method $^{1}$. All macroeconomic variables are expressed in local currency.

\section{II.2. Public and private capital stocks}

We disaggregate the total physical capital stock into public and private capital using the share of public investment in total investment; by applying the same depreciation rate of 0.04 as that used by Nehru and Dhareshwar (1993). Formally we have:

$$
\left\{\begin{array}{c}
\phi=(1 / T) I g_{t} / I_{t} \\
K g_{t}=\phi K_{t} \\
K g_{t}=(1-\delta) K g_{t-1}+I g_{t}
\end{array}\right.
$$

Where $\phi$ is the share average public investment $\left(I_{g}\right)$ in total investment (I). $K_{g}$ the public capital stock and K the total capital stock ${ }^{2}$.

In the absence of any other information on the value of public and private capital stocks, this construction method seems to us to be as neutral as possible.

The public capital stock should be understood as the discounted net sum of investments made by the public sector. It includes the capital stock in infrastructure held by the State but also the capital stock of public enterprises.

He does not understand, in revenge, the infrastructure capital stock belonging to the private sector. The privatization of a public enterprise is considered a divestment from the public sector. The distinction between the two stocks therefore obeys a criterion of ownership or heritage (Dessus and Herrera, 1999).

\section{II.3. Estimation method}

For all future estimates, we have used the fixed-effects model to process our panel. Hausman's specification tests confirm that the fixed-effects model is statistically preferable to the compound error model; which means that retaining the latter would lead to obtaining asymptotically biased estimators. In addition, the sample used is not the

\footnotetext{
${ }^{1}$ This method is based on the properties of the long-term equilibrium Solow model, which makes it possible to derive the capital stock as a function of the investment, the rate of depreciation and the rate of growth of the economy.

${ }^{2}$ It can be proved that the sum of public and private capital is equal to the total capital stock.
} 
result of a random selection by sampling method. This limits the scope of our results to the single population considered but justifies the deterministic nature of the individual effect within a sample considered to be exhaustive. We are therefore only interested in the intra-country evolution of GDP and public and private capital stocks. Each level variable is transformed using the intra operator (within), which amounts to dealing only with deviations from the individual averages for each country. Thus, for all the estimates concerning level variables, we perform a transformation consisting in subtracting from each variable the average per country of the same variable over the period studied, namely:

$$
y_{i, t}=Y_{i, t}-\left(\frac{1}{T}\right) \sum_{t=1}^{T} Y_{i, t}
$$

The estimators and the residuals obtained from the transformed variables are strictly identical to those which one would obtain by introducing a dummy variable per country in an equation where the variables would be in level according to the Frisch-Vaugh theorem. The statistics reported subsequently only describe the part of the dynamic $R^{2}$ intra-country information that our models manage to explain and in no case the information contained by the differences in levels between countries. Given our growth problem, the intra variance is obviously much more instructive than the inter (between) variance which only reflects the permanent and invariant differences between countries on which economic policy by definition has no influence.

If we assume that the share of investment in infrastructure capital in total public investment is constant by country over the period studied, then the use of the operator -within reinforces the spatial homogeneity of the stocks of public capital $^{3}$.

\section{Presentation and estimation of the model III.1. Simultaneous Equation Models}

We estimate in logarithmic form, and after transformation of the variables by the intra operator, a system of three simultaneous equations, comprising: a product equation, an equation of demand for public and private capital. The index $i$ represents the country and the period:

$$
\left\{\begin{aligned}
Y_{i, t} & =\alpha_{G} K g_{i, t}+\alpha_{p} K p_{i, t}+\alpha_{H} H_{i, t}+\alpha_{O} O u v_{i, t}+\alpha_{U} P G F_{t}+\alpha_{i} T_{i, t} \\
K g_{i, t} & =\beta_{Y} Y_{i, t}+\beta_{p} K p_{i, t}+\beta_{D G} D g_{i, t}+\beta_{D P} D p_{i, t}+\beta_{G} K g_{i, t-1}+\beta_{i} T_{i, t}(3) \\
K p_{i, t} & =\gamma_{Y} Y_{i, t}+\gamma_{G} K g_{i, t}+\gamma_{D G} D g_{i, t}+\gamma_{D P} D p_{i, t}+\gamma_{p} K p_{i, t-1}+\gamma_{i} T_{i, t}
\end{aligned}\right.
$$

The production function is of Cobb-Douglas type three factors public capital private capital (and human capital (H). We suppose that this function is homogeneous of degree 1 (constant returns). To these accumulable production factors are added two variables intended to explain the Solow residual. The first is the rate of openness of the economy (Ouv) measured by the ratio of exports plus imports to GDP. This variable measures the gradual integration of the national economy into the world market, a positive on growth through a better allocation of factors and thereby an increase in overall factor productivity $\left.\left(K_{g}\right) K_{p}\right)^{4}$. In addition, the internationalization of the economy favors technology transfers from which the least technologically advanced countries can benefit at a lower cost. In doing so, we also introduce as an explanatory variable, an index representative of the total factor productivity in Cameroon (TFP). This variable measure how quickly the least advanced countries capture the most recent technologies (Barro and Sala-i-Martin, 1995). It can also be interpreted as a measure of the external shocks facing the economies considered. We will see that these attempts to explain the Solow residue allow to significantly improve the quality of the estimates.

Human capital is considered here as being exogenous. From an economic point of view, it would be wise to think that neither the labor force nor the average number of years of schooling of this population is the result of a demand for short-term factors. It would have been preferable to use the number of hours worked as a work variable and the

${ }^{3}$ This transformation makes it possible to homogenize our series. So, for example, converting our variables into a common currency is unnecessary. Indeed, the multiplication of the variables by the exchange rate of the base year only affects the fixed effect, since our variables are expressed in logarithms.

${ }^{4}$ See Harrisson [1996] for a detailed presentation of empirical work on the relationship between growth and openness. 
human capital of the employed population (rather than the total). This will not be the case, because of the lack of reliable data on the work of the developing countries considered. With regard to econometric modeling, the weak exogeneity tests ${ }^{5}$ carried out on human capital do not make it possible to reject the null hypothesis according to which this variable can be considered as exogenous. On the other hand, these same tests applied to the stocks of public and private physical capital significantly reject the hypothesis of exogeneity of these variables, which it is therefore necessary to introduce endogenously.

The demands for public and private capital is derived from a flexible accelerator type model. The minimization of the cost of production implies an elasticity of demand for factors with respect to the product equal to a long run. The capital stock $\mathrm{K}$ then adjusts to the long-term target ${ }^{6}$ according to the following formula:

$$
K_{t}=\lambda Y_{t}+(1-\lambda) K_{t-1}
$$

The factor price ratio is absent from the demand equations, the user costs of public and private capital (which depend on the interest rate and the price of capital goods) being assumed to be similar. However, in the short term, we can admit that the supply of financing means is not perfectly elastic. Assuming that the domestic savings rate is constant in the short run, the adjustment is made by an inflow of foreign savings.

It is therefore safe to say that since the 1990s a logic of imbalance has prevailed in the process of indebtedness (Eaton Gergovitz and Stiglitz, 1986). The volume of loans then depends on the anticipated creditworthiness of the debtor rather than on the interest rate. It is assumed that the debtor's solvency is a negative function of its debt ratio $\mathrm{D} / \mathrm{Y}$. This reasoning is applied by distinguishing the external financing constraints specific to the public and private sectors, which leads to the introduction, respectively, of public and private debt ratios and into each of the capital demand equations. Thus we can observe a possible differentiated effect of external financing constraints on capital formation. $\left(D_{g} D_{p}\right)$

This external constraint adds an internal constraint on the distribution of available savings between the public and private sectors through a traditional crowding-out effect which justifies the presence of the public capital stock in the private capital equation and so on.

\section{Empirical results}

The model is estimated using the triple least squares method in order to reduce simultaneity bias. The heteroskedasticity problems are mitigated by introducing linear trends specific to each country. The White tests carried out do not allow the hypothesis of homoscedasticity of the residuals to be rejected and, on the other hand, reject the specifications of the model without country trends. ${ }^{7}$. Like the other variables, these trends are stripped of their individual means and therefore centered and of zero mean. The reports always greater than $90 \%$ therefore only reflect the part of the intra variance explained by the model for each of the equations and not the variance contained in the permanent differences between countries. $R^{2}$

The empirical results are presented in the table which proposes two systems of simultaneous equations, the first corresponding to the first three columns is the result of a free estimate while the second constrains the returns to scale to be constant to be constant ( either and the long-term elasticity of capital demands with respect to the product

\footnotetext{
${ }^{5}$ The tests consist in introducing the estimated residuals of the reduced forms of the capital equations of a simultaneous model into the structural equation of GDP. A residue whose coefficient is significantly non-zero makes it possible to reject the hypothesis of weak exogeneity of its associated capital. These tests make it possible to observe that only human capital is exogenous.

${ }^{6}$ The rationale for this specification is to base the symmetrical expression of the public and private capital stock equations on solid theoretical foundations. The fairly restrictive conditions of validity of the accelerator assume, however, that the relative factor costs are constant; acceptable approximation in an open economy for the cost of capital and with exogenous population dynamics for the cost of labor.

${ }^{7}$ The same equations estimated in first differences make it possible to observe results very similar to those presented in the table, which reinforces the robustness of our results.
} 
IRA-International Journal of Management \& Social Sciences

to be equal to unity (or in accordance with our theoretical model. The results of the estimation of the two systems are very $\operatorname{similar}\left(\alpha_{P}+\alpha_{G}+\alpha_{H}=1\right)\left(\beta_{Y}+\beta_{G}=1 \text { et } \gamma_{Y}+\gamma_{P}=1\right)^{8}$.

Board. Simultaneous Estimates of Public Capital and Private Capital GDP Equations

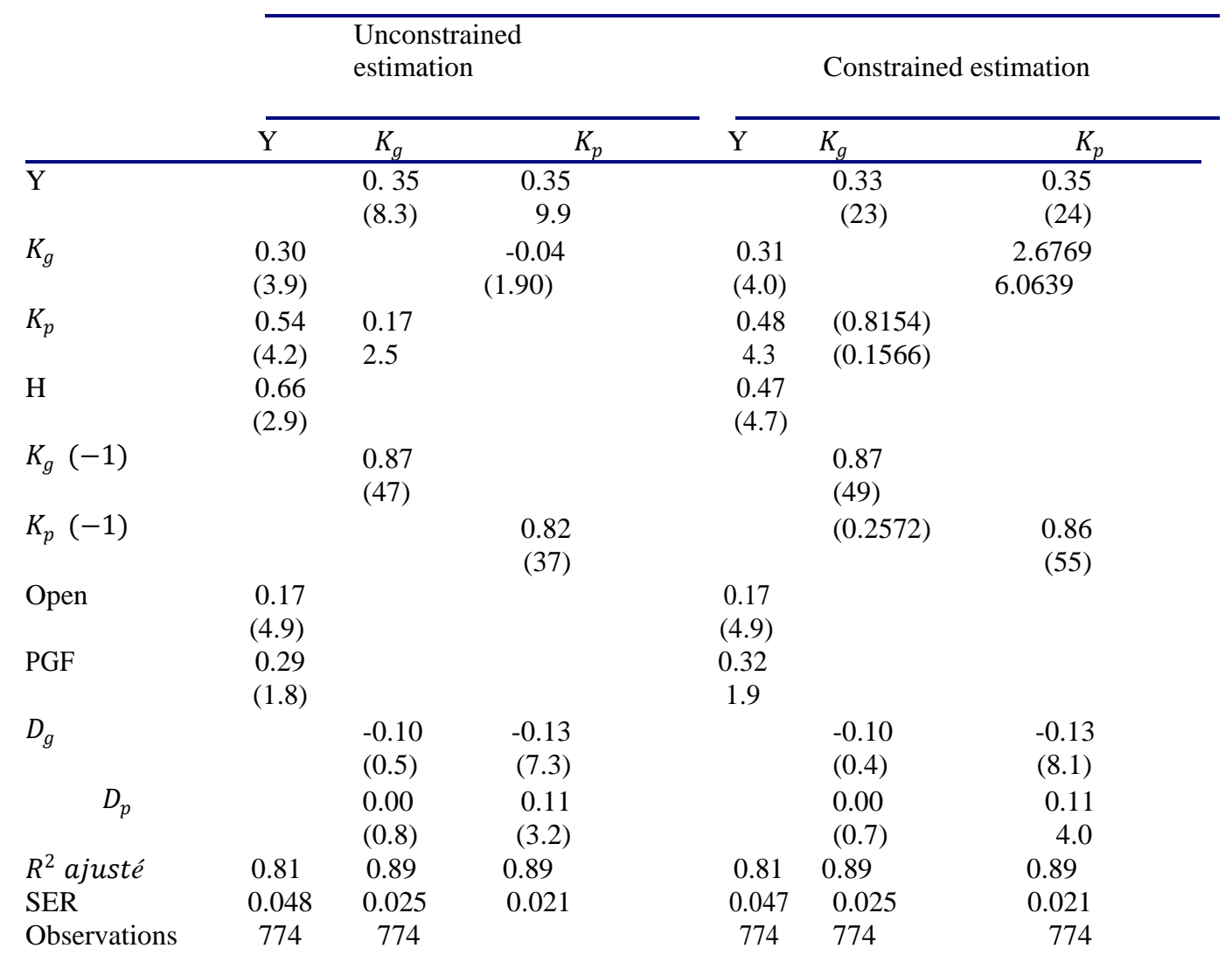

Notes. The variables are expressed in logarithm as a deviation from the country average (intra). The only describe the part of the explained intra variance. Statistics in parentheses are t-Student. Y: GDP, $K_{g}:$ public capital, $K_{p}:$ private capital, H: human capital Ouv: openness rate, TFP: total factor productivity in Cameroon delayed one year, public external debt / PEB, $R^{2}, D_{g}: D_{p}$ :private external debt / GDP. Simultaneous estimates in triple least squares with country trends. Instruments: $Y(-1) K_{g}(-1)$, Ouv, DGP, $K_{p}(-1) H, H(-1) D_{g}, D_{p}$,

We observe that the value of the coefficients of the production function is economically plausible ${ }^{9}$. The stock of public capital contributes positively and statistically to the growth of the GDP with an elasticity of the order of 0.30 a little less than two times lower than that of private capital 0.54 . At this level of the analysis, the annual implicit rate of return on public capital can be calculated from the value of the elasticity of the product to this stock. $\left(\alpha_{g}\right)$ and the coefficient of public capital, according to: $\left(Y / K_{g}\right)$

$$
\frac{\partial Y}{\partial_{K_{g}}}=\alpha_{G} \frac{Y}{K_{g}}
$$

We note that human capital is also a key element of growth that is statistically significant and quantitatively important (an elasticity close to 0.5). On average, a skilled worker is therefore more productive than an unskilled worker; a more skilled workforce adapts better to technological change and demonstrates greater mobility in the

\footnotetext{
${ }^{8}$ The Wald test in no way makes it possible to reject the hypothesis of constant returns to scale or that of the long-
} term uniqueness of the respective elasticities of the two types of capital to the product.

${ }^{9}$ The results we obtain for the production function are close to those reported by Nehru and Dhareshwar 1994. 
labor market. The importance of this positive result should be emphasized because the empirical verification of the contribution of human capital to growth often poses a problem in the literature (Benhabib and Spiegel, 1994), Berthélemy Dessus and Varoudakis (1997). Our method of building human capital assumes perfect substitutability between skilled and unskilled labor ${ }^{10}$. By removing this hypothesis, and by separating the active population and the average number of years of studies per capita, only this last variable remains statistically significant with an elasticity close to that obtained for the product of the two variables. The value and significance of the elasticity of GDP to human capital, robust to changes in specification, therefore confirms the overall consistency of our estimates.

The public and private capital equations highlight the problem of the domestic breakdown of savings. If the public and private sectors have a long-term target (i.e. long-term elasticity with respect to GDP) and a speed of adjustment (measured by the coefficient of the lagged endogenous variable) to this target that are very similar, they perceive very different funding constraints. This crowding-out effect of private capital in favor of public capital appears in the private capital equation where the parameter associated with public capital has a negative sign but only slightly significant. On the other hand, the external financing constraint seems to be borne only by the private sector. Surprisingly, the public debt ratio does not affect the formation of public capital here, so it significantly limits the formation of capital in the private sector. This result suggests that the public sector could have kept a weak budget constraint by transferring the weight of its external debt to the private sector (by increasing the fiscal pressure, an inflationary tax or a financial repression differentiated between sectors). Private external debt appears, on the other hand, as a means of financing the accumulation of private capital. an inflationary tax or financial repression differentiated between sectors). Private external debt appears, on the other hand, as a means of financing the accumulation of private capital. an inflationary tax or financial repression differentiated between sectors). Private external debt appears, on the other hand, as a means of financing the accumulation of private capital. ${ }^{11}$.

As might be expected, the openness of the economy promotes growth; the potential for technological improvement measured by the total factor productivity index in Cameroon is a positive sign, statistically significant, thus contributing to a better estimate of the production function.

\section{$V$. The role of institutions in the economic development of African countries}

There is no theoretical consensus between theorists of endogenous and exogenous growth, between the supporters of public intervention or of the market, in the debate on the various development strategies.

The works of Rostow were already asking themselves the question of knowing from what institutional transformations has the take-off been able to take place? It is obvious that the institutions, guaranteeing the right to property and administering it, constitute a foundation on which capitalism has been able to build itself. Contract law is inseparable from the market economy. The establishment of "democratic" institutions facilitates development. The balance between the three powers (executive, legislative, judicial) guarantees the emergence of rules favorable to equitable development.

It would therefore be incongruous to ask whether institutions should play a role in the economic development of African countries - this is generally the case - but rather to qualify this role. Indeed, the question is whether only economic mechanisms allow countries to develop. Can development take place on its own through a process of selfregulating accumulation? In the event of a positive response, the institutions would play a passive or preliminary role or a framework for development. Otherwise, they would be determined by development itself, which would update and renew the institutions it needed. Two very different approaches can be found here:

First, the liberal perspective of development such as the Washington consensus, theories of endogenous growth or Solow's theory of convergence. It stipulates that development is conceived as a natural catch-up phenomenon, in which institutions will play only a small role.

\footnotetext{
${ }^{10}$ See Sala-i-Martin 1994

${ }^{11}$ These results confirm by specifying those that we obtain without differentiating the debt between public and private sectors to explain the formation of capital. In this case, we come to the conclusion that only private sector capital formation is negatively (significantly and strongly) affected by an increase in the total external debt ratio (public plus private).
} 
Then, the supporters of State intervention, through institutions supposed to promote development. This second approach therefore refers to a major question: the institutions specific to capitalism and resulting in "mass consumption", the ultimate stage of development according to Rostow, are they "universal" or are other institutional forms possible? If so, then the role of institutions is to facilitate the establishment of such a development model.

According to A. Sen (1987),development results from the increasing involvement of men in the production process. The institutions must then allow the development of their "capabilities". Certain institutions can play this role: this is the case of microcredit establishments. The experience of the "Grameen bank" created at the initiative of Muhammad Yusuf in Bangladesh can illustrate this point. Indeed, the bank by mainly lending small sums to poor women, makes them solvent and allows market integration that allows them to get out of the vicious circle of poverty.

Thereby, according to Williamson, he agrees to select the most adequate institutions to facilitate the development of the economy, on the basis of the minimization of transaction costs. Thus, certain institutional forms will no longer be suitable, because they will no longer be able to promote the development of businesses: liberal, extroverted modes of development where institutions have played a structuring role (the case of Great Britain) or else the modes of development. development where institutions have played a very interventionist role (self-centered development). The example of Botswana can illustrate this point very well.

\section{Conclusion}

We econometrically estimated a growth model that simultaneously explains the determinants of GDP and public capital stocks. Our results suggest that the stock of public capital has a significantly positive impact on long-term growth. The robustness of the estimate of the contribution of public capital to growth is confirmed by the overall consistency of the estimated production function, which also integrates private and human capital with equally positive and statistically significant roles in growth.

The plausibility of these results is reinforced by the values of the implicit rates of return on public and private capital stocks found to be quite close to each other for the forty-three developing countries considered. Our understanding of public capital does not allow us to distinguish infrastructure from other types of public investment. The determination of the concept of public capital is still relevant and our results, despite being robust, must be enriched by the use of alternative definitions of the stock of public capital and / or infrastructure.

Finally, to whether institutions are a prerequisite for economic development (thesis of the institutionalists)? Or are they the product? In the first case, their role is structuring and therefore essential to the development process. In the second case, the implementation of development is gradual and the transformation of institutions results from the growth of a "modern" sector compared to a "traditional" sector. In this case, their role is to promote the transition from one mode of development to another. There can be conflict between "modern" and "archaic" institutions, as we can see today in some African countries.

\section{References}

[1]. Amartya Sen (1999), Commodities and capabilities, Oxford University Press.

[2]. Arrow KJ and Kurz (1970). Public Investment the Rate of Return, and Optimal Fiscal Policy, Baltimore, The Johns Hopkins Press.

[3]. Aschauer (1989). Is Public Expenditure Productive? Journal of Monetary Economics, 23, 177-200, May.

[4]. Barro RJ (1990). Government Spending in Simple Model of Endogenous Growth, Journal of Political Economy, 98 (5), part II, S103-S125, October.

[5]. Barro RJ and Sala-I-Martin (1995). Economic Growth, New York McGraw-Hill.

[6]. Benhabib and Spiegel MM (1994). The Role of Human Capital in Economic Development Evidence for Aggregate Cross-Country Data, Journal of Monetary Economics, 34, p.143-173.

[7]. Berth Lemy J.-C. Dessus and Varoudakis (1997). Human capital and growth: the role of the trade regime, Revue économique, 48 (3), May, p.419-428.

[8]. Berth Lemy J.-C. Herrera and Sen (1995). Military Expenditure and Economic Growth: An Endogenous Growth Perspective. Economics of Planning, 28 (2-3), p. 205-233.

[9]. Dessus S. and Herrera R. (1999). Public capital and growth: a study in panel econometrics. Economic review, volume 50, n 1, pp. 113-126. 
IRA-International Journal of Management \& Social Sciences

[10]. Eaton J. Gergovitz and Stiglitz (1986). The Pure Theory of Country Risk. European Economic Review, 30, p. 481-513.

[11]. Gramlich EM (1994). Infrastructure Investment Review Essay, Journal of Economic Literature, 32, p. September 1176-1196.

[12]. Nehru and Dhareshwar (1993). New Database on Physical Capital Stock Sources Methodology and Results. Revistas de Analisas Economico, 8 (1), June, p. 37-59.

[13]. Nehru and Dhareshwar (1994). New Estimates of Total Factor Productivity Growth for Developing and Industrial Countries. Policy Research Working Paper, No. 1313, International Economic Department, The World Bank, Washington, DC.

[14]. Rostow (1960). The stages of economic growth. Translated from the American by M.-J Du Rouret. Economic review, Year 1965, 16-4, pp. 629-630.

[15]. Sala-I-Martin (1994). Measures of Aggregate Value of Human Capital. Seminar Paper. International Monetary Fund, Research Department, August. 